\title{
Erratum to: Molecular characterization of Giardia duodenalis in dogs from Brazil
}

\author{
Flávio M. Paz e Silva • Marina M. Monobe • \\ Raimundo S. Lopes • João P. Araujo Jr
}

Published online: 2 August 2011

(C) Springer-Verlag 2011

\section{Erratum to: Parasitol Res}

DOI: 10.1007/s00436-011-2492-3

The original version of this article unfortunately contained a mistake. The name of author Flavio M. Paz e Silva is wrong. The correct author name is: Paz e Silva, FM

So, correct citation of this article is:

Paz e Silva FM, Monobe MM, Lopes RS, Araujo Jr JP. Molecular characterization of Giardia duodenalis in dogs from Brazil. Parasitol Res. 2011 Jun 22. [Epub ahead of print]. DOI: $10.1007 / \mathrm{s} 00436-011-2492-3$

The online version of the original article can be found at http://dx.doi.org/ 10.1007/s00436-011-2492-3.

F. M. Paz e Silva $(\bowtie) \cdot$ M. M. Monobe $\cdot$ R. S. Lopes Laboratory of Parasitic Diseases, Department of Veterinary Clinic, Faculty of Veterinary Medicine and Animal Science, UNESP - Univ Estadual Paulista, Botucatu, São Paulo, Brazil e-mail: flaviopaz@hotmail.com

M. M. Monobe

e-mail: mitie.vets@yahoo.com

R. S. Lopes

e-mail: souzalopes@fmvz.unesp.br

M. M. Monobe $\cdot$ J. P. Araujo Jr

Laboratory of Molecular Diagnosis,

Department of Microbiology and Immunology, Biosciences Institute,

UNESP - Univ Estadual Paulista, Distrito de Rubião Júnior,

S/N, 18618-970, Botucatu, São Paulo, Brazil

J. P. Araujo Jr

e-mail: jpessoa@ibb.unesp.br

Present Address:

F. M. Paz e Silva

Laboratory of Molecular Diagnosis,

Department of Microbiology and Immunology, Biosciences Institute,

UNESP - Univ Estadual Paulista, Distrito de Rubião Júnior,

S/N, 18618-970, Botucatu, São Paulo, Brazil 